\title{
The Concept of Creativity and Innovativeness Assessment in Business Organizations
}

\author{
Irena Mačerinskiené ${ }^{1}$, Aleksandra Bulygina ${ }^{2},{ }^{1-2}$ Mykolas Romeris University
}

\begin{abstract}
The article analyses creativity and innovativeness in organisations of service business in Lithuania. Relation between creativity and innovativeness is given, and concepts of creativity and innovativeness, as well as the main research models, are presented. Statistical data and questionnaire survey data analyses are used for the research of the factors of creativity and innovativeness in Lithuania. Research results have shown that more than half of the organisations of the service sector in Lithuania are assessed as not creative; also factors that stimulate creativity are not sufficient for the development of creativity. It is necessary to create a work environment favourable for innovations that would help reveal and develop the creativity of human capital.
\end{abstract}

Keywords: creativity, innovativeness, assessment of creativity and innovativeness, creativity potential

\section{INTRODUCTION}

The discussion about creativity and the importance of its encouragement in European regions started in the economically developed countries of the European Union (EU) back in the $20^{\text {th }}$ century. Joseph Schumpeter (18831950 ) is one of the best known representatives of the Austrian School of Economics, who developed the theory of economic cycles and development that considered new innovations and the creative destruction process to be its main factors. These factors help business subjects to remain competitive and determine the development of economics; therefore, their development is more often acknowledged as a strategic priority. In the Lisbon Strategy, approved by the European Council in 2000, the importance of a constant development of innovations is emphasized. Although the aims set at that time have not been reached yet, the perceived importance of creativity and innovativeness stimulated scientific research in this area. The year 2009 was announced as the year of creativity and innovativeness in the EU. Based on the newly oriented Lisbon Strategy, the European Commission raised a goal to encourage people to think and act creatively and innovatively and, thus, help the EU member states better prepare for future challenges of globalisation. Creativity and innovativeness are considered to be the most important priorities that determine the development of economies.

The concepts of creativity and innovativeness have still not been fully developed. Disregarding the acknowledgement of the importance of creativity in the contemporary society, the attention of representatives of the socio-economic scientific area towards this issue remains insufficient. Firstly, it is considered that inventiveness is not economically significant, and the real economic value of a creative idea appears only when the innovation process is successfully finished $[20, p$. 361]. Secondly, it is stated that it is impossible to model inventiveness: "in other words, creativity cannot be received according to a formula" [20, p. 361]. These preconditions determine the fact that scientific research focuses more on the analysis of innovativeness than that of creativity. Creativity is a necessary part of innovativeness; therefore, research on creativity may help better understand the process of innovation development. Scientific sources try to explain the essence of creativity by assessing creative abilities, creative thinking, and the result of creation from various aspects. The recent studies of foreign countries show a tendency of assessing creativity as a phenomenon that may be expressed in all aspects of life. Various scientists investigate creativity of organisations in different aspects, which is often analysed as a manifold phenomenon that encompasses individual, collective, and organisational levels. Performed studies on the influence of work environment on creativity clearly show that it is not enough to hire creative employees, it is necessary to make efforts forming an environment favourable for creativity. Performed studies $[4,5,7,25,29]$ identify various factors that stimulate creativity in organisations and present different models of creativity assessment in a business organisation. Favourable conditions for creativity formed in organisations add to the development of innovations; therefore, it is necessary to research factors that stimulate creativity.

The research problem. Are there favourable conditions for the development of creativity and innovativeness in business organisations of the service sector in Lithuania and what factors stimulate their development?

The research object is creativity in business organisations of the service sector in Lithuania.

The research goal is to identify the condition of creativity of business organisations of the service sector in Lithuania and to foresee directions for the increase of its potential.

\section{MODELS OF ORGANISATIONAL CREATIVITY AND INNOVATIVENESS ASSESSMENT}

Creativity is related to innovations that lead to the development of new areas of commercial activities, better products and stronger competitive situation of current business [15]. Innovation is defined as a process during which new ideas, technologies, and methods are applied commercially introducing new products into the market or improving existing products and processes [14]. Creativity is described as an ability to think in an original and unusual way, as a specific personal characteristic, as a process and a creative result received during it $[13 ; 21 ; 22]$. It is emphasized that creative ideas must be acknowledged and practically applied in order to be useful for others, in other words, they must be converted 
into a certain form - a product or a service. Expressing the connection between the conceptions, the authors $[9 ; 17 ; 23$; 26] assess creativity as a precursor of innovations. No innovation in an organisation may be reached without an individual creative action of its employee [24]. Burbiel (2009) also emphasises that creativity is necessary even before the factual beginning of the innovation application process; therefore, creativity may be considered to be the source for innovativeness, which in turn conditions the appearance of scientific, technological, or process innovations [8]. The concepts of creativity and innovativeness are so closely related that some authors use them as synonyms [2; 17]. Joachim Burbiel (2009), a researcher at the Fraunhofer Institute for Technological Trend Analysis (Germany), states that creativity, defined as a combination of idea generation and suitability acknowledgement, is necessary in the whole innovation creation process because innovative ideas must be added to it anew all the time [8]. Acknowledging that creativity is applied to all stages of the innovative process, thus, we decrease the differences in these concepts even more. According to Mats Sundgren and Alexander Styhre (2007), researchers at the Chalmers University of Technology (Sweden), some researchers state that the distinguishing property of creativity and innovativeness is most often just emphasized but intangible [27]. The difference between them may be expressed when creativity is treated as the generation of innovative ideas, and when innovation is considered the practical implementation of these ideas.

Amabile (1997) demonstrated the relation between individual / collective creativity and organisational innovation in the model of factors that guarantee organisational creativity (see Fig. 1).

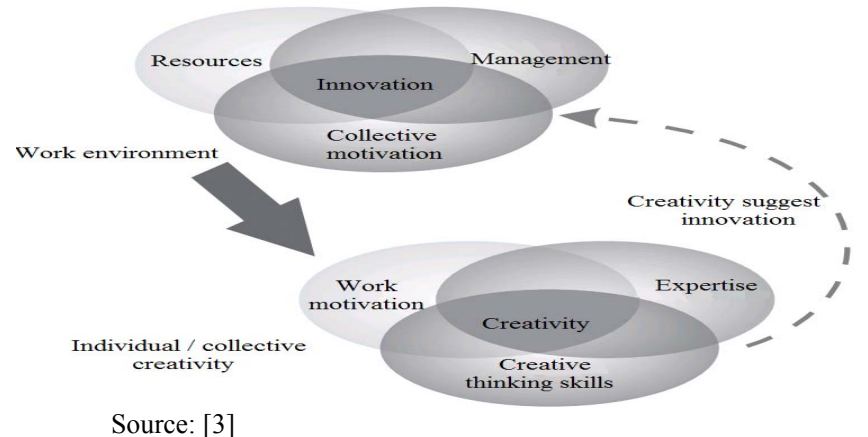

Fig. 1. Model of factors that guarantee organisational creativity and innovativeness.

This model is based on the thorough research results of Amabile and states that factors of a work environment (such as organisational motivation, resources and management methods) are significantly connected with organisational creativity (of each employee or / and of employee groups), for the stimulation of which creative skills, expertise, and work motivation are required. Three main work environment factors that impact organisational innovativeness are distinguished, and they are described as follows:

1. organisational motivation to constantly create and be innovative is the main orientation of an organisation towards innovations; besides, it also promotes and sustains creativity and innovativeness in the whole organisation;

2. resources are related to everything that is in the disposal of an organisation seeking to support innovative activities and their efficiency: sufficient time resources allocated to a new assignment, training possibilities, etc.;

3. management methods with the following features: freedom or autonomy when performing own work, which would be interesting and challenging and would provide employees of the organisation with a possibility to develop; identification of clear all-encompassing strategic objectives and formation of work teams, engaging people with different skills and thinking.

These factors create conditions for the development of creativity and adaptation of individual creative ideas in the innovative process. Innovativeness needs not only a favourable work environment but also individual employee creativity and collective creativity. Individual creativity consists of expertise, creative thinking skills, motivation, and interaction of all these elements.

- Creative thinking skills are a person's abilities to solve problems in a flexible and creative way, to join known ideas into new and significant combinations. But without the necessary expertise creativity skills will not help an individual to make creative decisions for solving work-related problems [16].

- Expertise is all technical, functional, and intellectual knowledge that a person has in a certain area of activities. Thus, if a person wishes to be creative, he/she must have expertise. Although the expression of creativity in an organisation depends on individual thinking skills and expertise, their motivation during the performance of a certain task also plays a very important role;

- Employee motivation in an organisation may be stimulated by external and internal motives. External motivation may be expressed by financial compensation that stimulates a person for creative activities, and most often it is acceptable for those individuals, who are inclined to look for the most effective ways of problem-solving seeking to receive the desired compensation. But inner motivation is more efficient because individuals are significantly more creative when tasks raise their interest, satisfaction, and challenge, and, therefore, it is considered to be the main stimulus for creativity.

Research confirms that the higher the degree of each of these factors in an organisation, the bigger the expression of creativity and innovativeness in it. In the research of Amabile $[3 ; 4 ; 5 ; 6 ; 7]$, where the stimulation of employee creativity is assessed, the importance of inner employee motivation and social environment is especially distinguished.

The interactionist organisational creativity model suggested by Woodman et al. (1993) [29] is often analysed and applied when researching organisational creativity assessment. This model encompasses the levels of individual, group, and organisational creativity. Defining creativity factors present in these levels the value of organisational creativity is received. 
1. individual characteristics are the basis for their interaction and depend on each individual's cognitive abilities / cognitive style (i.e., certain mental processes, e.g., ability to recognise new problems, to assess them, analyse and plan their solution methods); personality; inner motivation; suitable knowledge;

2. group characteristics consist of certain norms; harmony (balance between group needs and individual needs of the group members); group size, member diversity, and role distribution; possibilities of task performance and methods of problem solution used in the group;

3. organisational characteristics encompass organisational culture, resources, and compensation systems and focus on organisational strategy, structure, and technologies.

Individual, group and finally organisational characteristics have a direct influence on the creative process and circumstances that determine the appearance of the organisational creative product - innovations. The distinguishing of the levels of creativity used in the model of Woodman et al. (1993) is also used in other creativity assessment models.

Jeffery D. Houghton (2008) composed a conceptual creativity research model that encompasses three factors. He confirmed the validity of the model of distinguished conceptions with the help of the method of factorial analysis. The elements of creative potential, adapted creativity and perceived organisational support are distinguished. The difference between creative potential and adapted creativity in an organisation can depict important unused resources that could stimulate innovations, productivity, and bigger satisfaction by performed work if they were used properly. A researcher from the Open University of the Netherlands Ben Chini (2011) [10] expanded constructions of conceptions of creative potential and adapted creativity by DiLiello and Houghton (2008) [11], having applied eight "KEYS scales" of work environment factors identified by Amabile et al. (1996), which are organisational encouragement, leader / managerial encouragement, support of the work group, freedom, sufficient resources, challenging work, work load, organisational obstacles. These indicators are used to explain the difference between creativity potential and applied creativity. Research results have shown that organisational encouragement, challenging work, and a big workload are important factors for the implementation of creative potential.

Some of the main models of organisational creativity discussed most often in scientific literature of foreign countries are the models of organisational creative climate assessment and creativity and innovativeness guarantee factors of Amabile (1996; 1997), and the model of interactionist organisational creativity of Woodman et al. (1993) [28, 29] that shows interactions among aspects of individual, group, and organisational creativity. Also we can distinguish the creativity assessment model of Jeffery D. Houghton (2008), where organisational creativity potential and adapted creativity are separated. The difference between these factors shows unused resources of organisational creativity. This separation stimulated researchers to analyse factors that determine the efficient use of creativity potential more consistently.

\section{Methodology FOR ReSEARCH OF CREATIVITY AND INNOVATIVENESS}

Having analysed studies performed by foreign scientists on organisational creativity and the presented models, the main factors that have a favourable influence on creativity and innovativeness of a business organisation have been distinguished (for example, the ability of individuals in an organisation to solve problems creatively and innovatively, resource accessibility, work in groups, autonomy and freedom of decision-making, acknowledgement of employees, encouragement, compensation for creative ideas, tolerance, good inter-relations, etc.). Based on the structures of the conceptual models of DiLiello, Houghton (2008) and Amabile et al. (1996), a model for research of creativity and innovativeness of business organisations was drawn up that combined the identified factors (see Fig. 2).

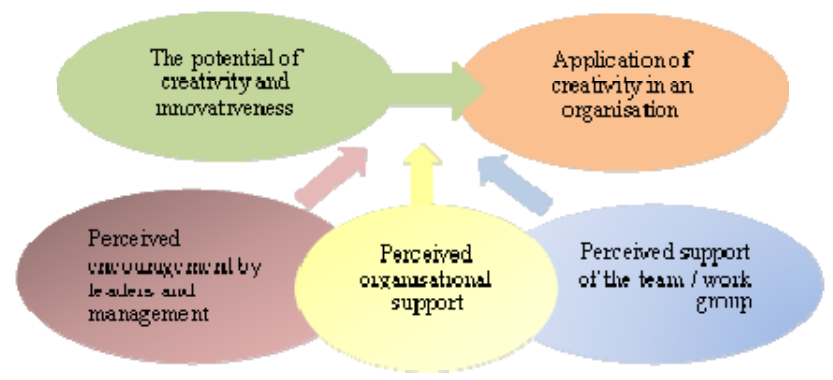

Fig. 2. Expanded model for research of creativity and innovativeness of business organisations.

The composed research model expands the construction of the model suggested by DiLiello, Houghton (2008) and encompasses important factors and aspects of organisational creativity revealed by foreign researchers that are considered to be very significant for a suitable assessment of organisational creativity and innovativeness. These factors are defined by five main constituents of the model: the potential for creativity and innovativeness in an organisation; application of creativity in an organisation; perceived organisational support; perceived encouragement by leaders and management; perceived support of the team / work group. Each constituent of the model has five factors that reveal it, and corresponding statements are used for their assessment.

Seeking to comprehensively assess creativity and innovativeness of Lithuanian business organisations of the service sector a decision was made to conduct research and to substantiate the received analytical assessment results with the help of the opinions of representatives of business organisations that helped identify the features of creativity and innovativeness. Each statement was assessed on the Lickert scale. A quantitative method - a questionnaire survey - was chosen for the research. Enterprises of the Lithuanian service sector were chosen as the general research set. To make the data of the research representative with a reliability coefficient 
of $95 \%$ for 76,891 objects of the general set, a set of 202 cases was sufficient. The survey was performed in February-March, 2012. A link to a research questionnaire was sent to respondents by e-mail based on their publicly accessible contacts from the information database www.visalietuva.lt. 500 questionnaires were sent out. The feedback rate of the research questionnaires was 49.6\%. 248 fully completed questionnaires were received. This survey allowed assessing the factors of competitiveness and innovativeness of Lithuanian service enterprises and conditions created within organisations for the development of creativity.

\section{CONDITIONS FOR THE DEVELOPMENT OF CREATIVITY AND INNOVATIVENESS IN LITHUANIAN ORGANISATIONS OF THE SERVICE SECTOR}

In Lithuania the speed of innovation development is one of the slowest in the EU. The biggest concern in the field of innovation development is raised by insufficient innovative activities of private enterprises [12]. The private sector rarely uses results of the country's scientists because their research directions are poorly related to business needs. Relations between participants of the innovation system are poorly related to studies, the education and training of researchers and other specialists. Such innovativeness indices as the general level of industrial technologies, the general level of expenses for scientific research and experimental development, the number of researchers working in business, the number of patents, design registration certificates, product brands are well behind the EU average. According to the total innovativeness index Lithuania is in the list of laggards among other EU countries (see Fig. 3).

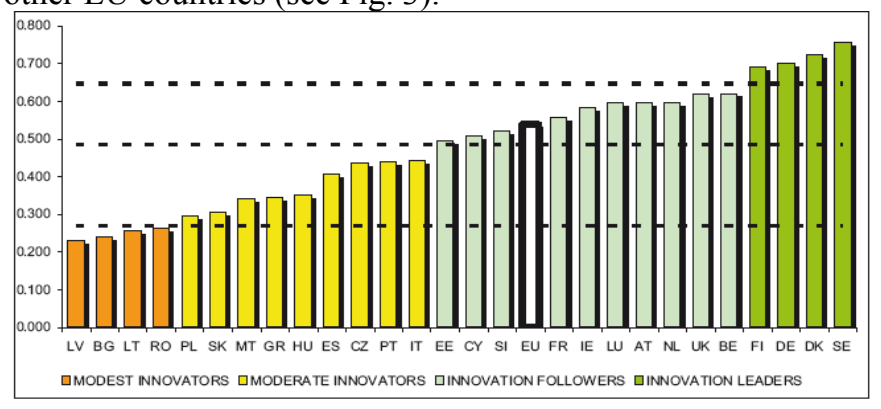

Fig. 3. Results of innovativeness application of EU member states according to the total innovativeness index, 2011 [12]

Poor assessments of innovativeness of Lithuania identify that the ability to develop innovations is one of the weaknesses of Lithuanian enterprises. According to the data of the Department of Statistics of the Republic of Lithuania only approximately a third of Lithuanian enterprises implement innovations. The percentage of enterprises that implemented innovations in 2002-2010 fluctuated by $6 \%$ and reached its highest value of $34.8 \%$ in 2004-2006. Later during 20062008 it decreased to $28.8 \%$ [19]. Currently a rise in the interest of possibilities of innovation implementation is seen. But the part of enterprises that implement innovations is quite small. Creativity is a precursor of innovations; its effect is necessary during the whole innovation process. The ability to create new valuable knowledge is the characteristic that could help
Lithuania accelerate the development of innovations. Each individual has an ability to create but the development of this ability and efficient use of the result of creativity depends on many factors. Further analysis concentrates on the research of creativity factors.

Enterprises of the service sector were chosen for the research of creativity. The service sector has a very important position in economics. In 2008-2011 the part of GDP in Lithuania generated by the service sector each year was more than 37\%. [18] This shows that this sector is very important with regard to business and the country's economics. This sector encompasses services of trade, education, business, lease, personal, health care, and social services. In 2008-2011 the number of service enterprises constantly increased from 72,389 enterprises in 2008 to 76,981 enterprises in 2011, i.e., there was an increase of $6.34 \%$ during the whole analysed period of time [18]. The establishment of new enterprises is often related to innovations that are used for the implementation of new projects due to entrepreneurship. Therefore, this sector should have a very big creativity potential.

248 enterprises of the service sector participated in the questionnaire survey. In the questionnaire survey organisations with the main seat in Vilnius County were predominant $(34.7 \%)$, also organisations with the main seat in Siauliai County (18.5\%) and Kaunas County (18.1\%) were distinguishable. According to the data of the Department of Statistics of the Republic of Lithuania in 2009 the biggest number of enterprises was registered in Vilnius County (37\%) and Kaunas County (20\%). $7 \%$ of all enterprises established in Lithuania in 2009 were registered in Siauliai County [18]. As it may be seen the distribution of enterprises that participated in the survey according to counties proportionally reflects the distribution of Lithuanian enterprises. Analysing the distribution of respondents according to types of business organisations it may be seen that $55.2 \%$ of organisations that participated in the research were closed joint stock companies. Also very many representatives of individual companies participated in the research $(28.6 \%)$. The biggest part of the enterprises that participated in the research were small enterprises with 10-49 employees $(30.65 \%)$ and medium enterprises with 50-249 employees (30.24\%); $25.81 \%$ of enterprises that participated in the research were microenterprises with 1-9 employees. The smallest part of respondents was big enterprises with 250 or more employees their percentage was $13.31 \%$. In 2012 the part of big enterprises in Lithuania accounted for only $0.54 \%$, so proportionally the number of big enterprises that participated in the research was bigger than in the researched population. The duration of activities of organisations participating in the survey was also analysed during the research. $31.45 \%$ of organisations participating in the research have been active for 6-10 years. Distribution of other organisations according to the duration of their activities is relatively the same: $20.97 \%$ of organisations have been active for 15 years or more, $16.13 \%$ - for $11-14$ years, $17.74 \%$ - for 4-5 years. The smallest part of respondents was organisations active for less 
than 3 years - their number was $13.71 \%$. It may be seen from this data that describes the enterprises under consideration that participants of the set are distributed in a quite representative way, there are no big exclusions that could have an impact on the representativeness of the data.

During the research when analysing creativity of organisations of the Lithuanian service sector it was sought to assess if respondents consider the organisation where they work / that they own to be creative. Results gathered during the questionnaire survey may be seen in Fig. 4.
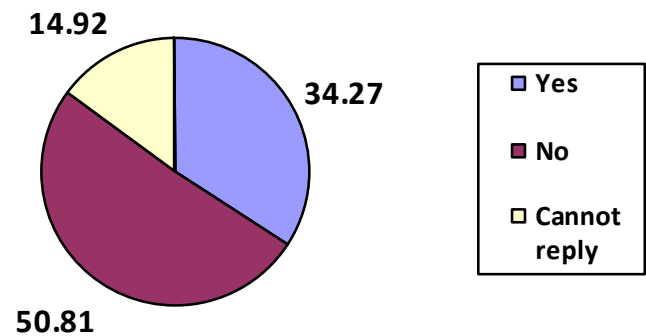

Fig. 4. Percentage of organisations that were named as creative.

According to the research results presented in Fig. 4 it may be seen that more than half of the respondents that participated in the research $(50.81 \%)$ consider the organisation in which they work not to be creative. $34.27 \%$ of the respondents consider the organisations to be creative, and $14.92 \%$ of the respondents could not reply to this question. Based on these results, it is possible to state that the respondents are not inclined to consider their organisations where they work, i.e., organisations of the Lithuanian service sector, to be creative. Statistical data show that only a third of enterprises in Lithuania implement innovations. Therefore, it is purposeful to analyse reasons that determine such a situation.

During the research it was sought to assess the creativity potential of organisations in the Lithuanian service sector with regard to respondents (see Fig. 5). It was evaluated how respondents perceived creativity potential of their organizations, indicators evaluated personal capabilities.

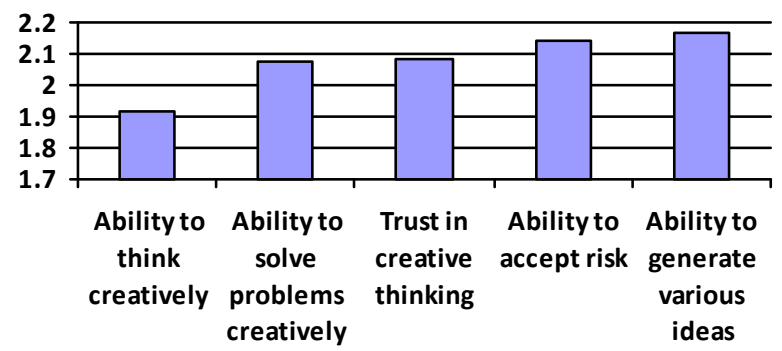

Fig. 5. Assessment of an organisation's creativity potential in an organisation.

The creativity potential in organisations is the creativity aspect, which received the lowest marks (2.077 on average) comparing with other main constituents of the proposed creativity model. This shows that respondents have a very critical assessment of their creativity possibilities and do not think they have necessary skills. According to the data in Fig. 5 , it may be seen that according to most respondents their ability to generate various new ideas is one of strongest fields of their creativity (average: 2.169). The respondents do not trust their ability to solve problems creatively (average: 2.085); therefore, they cannot find creative ways for problemsolving (average: 2.073). The worst evaluation by the respondents was of skills necessary for further development of ideas of other people (average: 1.919). Based on these results it is possible to state that the main problems of the creativity potential in organisations of the Lithuanian service sector are the following: lack of trust, i.e., the respondents do not trust their abilities; fear to risk; avoidance of creative methods for problem solution.

The assessment of application of creativity in organisations of the Lithuanian service sector is presented in Fig. 6. The average of assessments of creativity application in business organisations is 2.363 . The perceived average of creativity application is by 0.287 bigger than the assessment of organisational creativity potential. This shows that the perceived possibilities of organisational creativity application are bigger than the perceived organisational creativity potential. This shows a strange situation where more possibilities for creativity application are identified in organisations than of individual creativity and individual ability to develop innovative ideas. Such results may be related to cultural background of respondents. Respondents evaluate their ability more critically than environment factors.

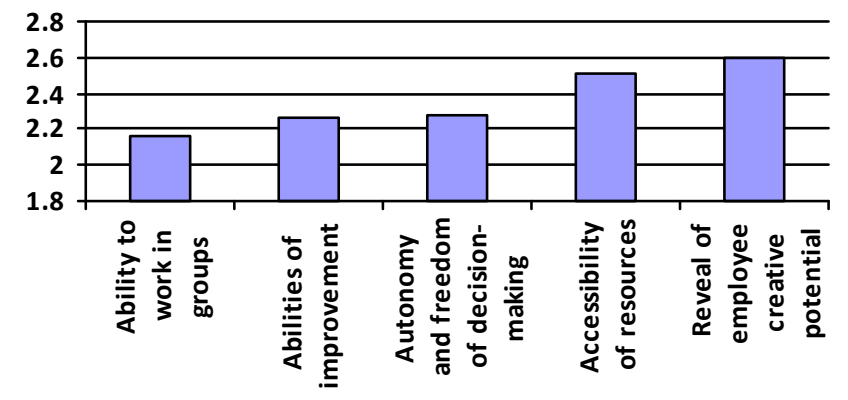

Fig. 6. Assessment of creativity application in organisations.

During the research it was determined that the application of creative abilities of the respondents in organisations of the Lithuanian service sector allowed revealing their full potential (average: 2.593); also the respondents could receive sufficient resources for the development and implementation of their ideas (average: 2.512). The respondents do not have much freedom to decide how to better perform their work tasks in organisations (average: 2.282); also there are no sufficient possibilities for the expression of creative skills and abilities (average: 2.262). The respondents assessed possibilities to participate in work groups or teams most poorly from all creativity application factors in organisations (average: 2.169). Based on these results, it is possible to state that organisations of the Lithuanian service sector lack the possibilities to develop personal creativity and use it when working in groups. Not enough attention is given to the development of creativity. Seeking to reveal and develop the organisational creativity potential more attention from managers is necessary. Results 
of perceived creativity application show that the environment for creativity development is not favourable. Often problems of team work and autonomy and freedom of decision-making arise.

Level of creativity is related to creativity supporting atmosphere. In the research, three groups of indicators are evaluated in order to characterize support for creativity (see Fig. 2). Organizational support for creativity factors helps evaluate if organizational procedures simulating creativity are used. Results show that employee's creative solutions are valuated and rewarded. The assessment of perceived organisational support for creativity is presented in Fig. 7.

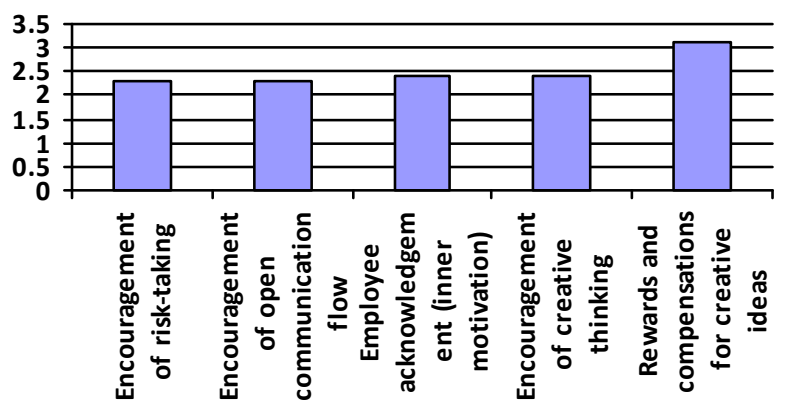

Fig. 7. Assessment of organisational support.

When analysing organisational support allocated for the development of creativity it may be stated that compensations and / or rewards are given in organisations for creative and innovative ideas (average: 3.137) (see Fig. 7). Based on this assessment of the respondents, it is possible to state that the main methods of organisational support of enterprises in the Lithuanian service sector are material incentives, which are the most favourable for recipients.

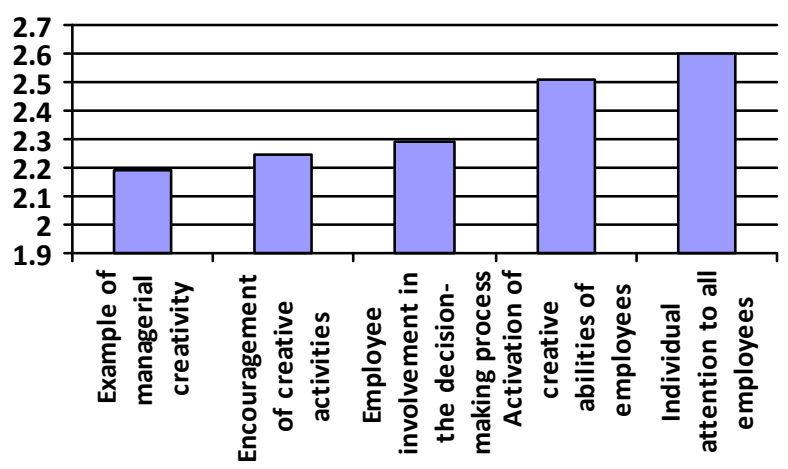

Fig. 8. Assessment of leader and managerial encouragement in an organisation.

Also employees in organisations are not only encouraged to solve arising problems creatively (average: 2.423 ), but they are also valued for creatively performed work and efforts (average: 2.419). Risk taking (average: 2.274) and open communication flow (average: 2.298) are topics that are encouraged the least in organisations. Based on these data, it is possible to state that it is purposeful to encourage risk taking and open communication flow in organisations of the Lithuanian service sector, thus stimulating the creativity of human capital and its use.

According to the data in Fig. 8, it may be seen that leader and managerial encouragement in organisations is perceived as insufficient. It is possible to distinguish that the most favourable assessment is for situations when organisational leaders and managers treat respondents like personalities and not like group members (average: 2.601). Distinguishing the personal input of employees increases motivation and is one of the elements of creativity.

The second most important element is encouragement of employees' creative abilities. An organisation's leaders and management encourage employee trainings in the areas of creativity and innovativeness development (average: 2.512), i.e., they activate creative abilities of employees. Other three factors have been evaluated by lower points - employees feel that they are insufficiently involved in the decision-making process, and information is not spread effectively. Leaders and management are assessed as lacking creativity and not encouraging creative thinking. Leaders and management of an organisation encourage to view problems from different points of view (average: 2.25), leaders and management of an organisation are an example of creativity (they look for new ideas and methods of problem solution) (average: 2.194). In summary, it may be noticed that in Lithuania the management does not pay much attention to encouragement of creativity.

Work environment is very important for the development of creativity. A perceived assessment of support by a team / work group in an organisation is presented in Fig. 9.

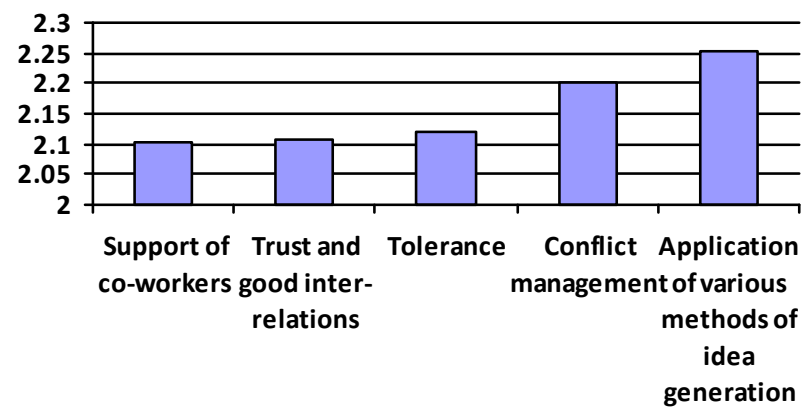

Fig. 9. Assessment of support by a team / work group in an organisation.

Research results have shown that relations in a team are not favourable for creativity. The lowest points were attributed to co-workers' support (average: 2.109) and trust and good interrelations (average: 2.101). Such a situation in a team is very unfavourable for the development of creativity and innovations. The respondents gave higher points to the abilities of application of various methods of idea generation (average: 2.254) and conflict management (average: 2.202). But these methods are not of much use if there is no trust in a team. Based on the performed analysis, it is possible to state that the support of the team is insufficient in organisations of the Lithuanian service sector; therefore, employee creativity is not influenced. 
Seeking to identify the importance allotted to innovations in service enterprises, a question was presented on the importance of innovations in their activities. The research results have shown that only $28.2 \%$ of organisations of the Lithuanian service sector indicated that innovations were not implemented or were implemented very rarely in their enterprises. Most often (24.5\%) innovations in organisations are developed according to needs, also most often $(24.2 \%)$ only marketing and management innovations are implemented. Only $16.9 \%$ of service enterprises constantly implement innovations. The part of enterprises that constantly implement innovations is by $3.3 \%$ lower than the part of enterprises that have never implemented innovations. This is a very negative indicator.

Summarizing research results it is possible to state that having performed the research on creativity and innovativeness of organisations of the Lithuanian service sector it has been determined that the situation in this area is very complicated. The total index of innovations in Lithuania allows stating that Lithuania is far behind other EU member states regarding many innovation indices. Even $28.2 \%$ of organisations in the service sector acknowledge that they have never performed innovations. Whereas the part of organisations that implement innovations, presented by the Department of Statistics, reaches only a third of all enterprises. The level of creativity that determines the development of innovativeness in organisations of the service sector is assessed as insufficient. More than half of all surveyed enterprises indicated that their organisations were not creative.

The detailed research of factors of creativity enabled to determine that in enterprises of the service sector the level of individual creativity was low, and favourable conditions for creativity development were not created. Creativity potential is evaluated with the lowest points. Employees do not have confidence in themselves, they are afraid of taking risks, and they avoid creative thinking. Conditions of creativity application in an organisation are assessed more favourably than abilities of the creativity potential, but the assessment of these conditions remains negative. The ability of employees to work in groups and possibilities of development seeking to reveal creativity are assessed as insufficient.

The perceived encouragement of creativity in organisations of the Lithuanian service sector is insufficient. Management members often do not encourage to think creatively and to apply innovations, also there is a lack of support of work teams and organisational atmosphere that would support creativity. Mutual trust is missing inside the organisations of the Lithuanian service sector, and that is an essential obstacle for innovation implementation.

\section{CONCLUSION}

Creativity in a business organisation is considered to be one of the most important factors of long-term competitiveness, and it acts on various levels and in various areas. Creativity helps an organisation adapt to the changing market conditions, constantly implement innovations, and keep its competitive advantage. The concepts of creativity and innovativeness are closely related. It is acknowledged that no innovation in an organisation can be reached without an individual creative action of its employee. Creativity is perceived as the source of innovativeness and a necessary element for innovation implementation. Therefore, an organisation that seeks to develop activities of innovations should encourage creativity.

Various factors influence creativity. Different authors identified various factors that stimulate creativity in organisations in their studies, and research models were drawn up based on these factors [25; Amabile, 1998, 1996; Woodman et al. 1993; 1, van den Berg, 2007). It has been noticed that some factors of organisational creativity (such as knowledge, cognitive style and abilities, personality, autonomy, freedom and inner motivation) are reflected in all models, but there is not one certain model that could be applied to various organisations. Assessment of the influence of organisational creative potential, applied creativity, organisational climate and management style favourable for creativity and innovativeness, and many other factors are predominant in works of contemporary foreign researchers. A model for research of creativity and innovativeness of business organisations that combines the identified factors was created with the help of the conceptual model structures of DiLiello, Houghton (2008) and Amabile et al. (1996). The model assesses creativity potential, application of creativity in an organisation, and perceived support for creativity. The perceived support for creativity is divided into organisational support; perceived leader and managerial encouragement; perceived support of the team / work group.

The performed assessment of creativity of service enterprises identified that creativity was a problematic area in the enterprises of the Lithuanian service sector. More than half of the organisations indicated that their organisations were not creative. All five groups of creativity factors in the creativity model were assessed by the respondents as not developed in their organisations. The main problems of the use of creativity potential and innovativeness in organisations of the Lithuanian service sector are the following: lack of trust; fear to risk; avoidance of creative problem-solving methods; lack of team work; lack of autonomy and freedom of decision-making; lack of the use of innovations in activities of organisations; lack of development according to needs; unmodified provided services, stagnation; lack of types of innovations applied in organisations.

The respondents assess their creative abilities in a very critical way and identify the lack of possibilities to develop creativity. Creativity is directly related to human resources and organisational environment. Human resources and motivation created by a creative environment may stimulate the appearance and development of creative ideas. Education, attitude, values, inner need for innovations, creativity, freedom of thinking are values that should be applied to knowledge employees; also it is a task for organisations to transform themselves implementing essential changes that should be oriented towards a harmonious development of the system that has personality as its integrate part. 


\section{REFERENCES}

[1] C. Andriopoulos, Determinants of organizational creativity: a literature review // Management Decision journal: the Emerald Management Science, Management Studies Subject Collection / Emerald Group Publishing Ltd. - 2001, Vol. 39, Nr. 10, p. 834-841. - ISSN 0025-1747;

[2] H. S. et al. Abdullah, Influence of Cultural Orientation on Perceived Organizational Creativity Climate: An exploratory study of Two Steel Plants in Malaysia // Asian Academy of Management Journal. - Minden, Penang, Malaysia: Asian Academy of Management, 2006, Vol. 11, Nr. 2 , p. 51-72. - Online ISSN 2180-4184;

[3] T. M. Amabile, Motivating Creativity in organizations: On Doing What you Love and Loving what you do // California Management review Berkeley, USA: Haas School of Business, University of California 1997, Vol. 40, Nr. 1, Fall, p. 39-58. - ISSN 0008-1256;

[4] T.M. Amabile, Creativity in context. - Boulder: Westview Press, 1996. 317 p. - ISBN 0-8133-2827-6 (hc). - ISBN 0-8133-3034-3 (pbk.);

[5] T.M. et al. Amabile, Assessing the Work Environment for Creativity // The Academy of Management Journal / Academy of Management. 1996, Vol. 39, Nr. 5, p. 1154-1184. - ISSN 0001-4273;

[6] T.M. et al. Amabile, User's manual for KEYS, assessing the climate for creativity - a survey from the CCL. - Greensboro, North Carolina, USA: Center for Creative Leadership, 1999. - 189 p.;

[7] T.M. Amabile, How to Kill Creativity // Harvard Business Review. Boston: Harvard Business School Publishing, MA, USA, 1998 (September-October) Nr. 5, p. 77-87. - ISSN 0017-8012;

[8] J. Burbiel, Creativity in research and development environments: A practical review // Int. Journal of Business Science and Applied Management. - UK: International Journal of Business Science and Applied Management, 2009, Vol. 4, Is. 2, p. 35-51. - ISSN 1753-0296;

[9] SC. et al. Chang, Social capital, creativity, and new product advantage: An empirical study // International Journal of Electronic Business Management / Electronic Business Management Society. - Taiwan, 2010 , Vol. 8, Nr. 1, p. 43-55. - ISSN 1728-2047;

[10]B. Chini, Developing Organizational Creativity: Researching contextual factors that enhance or restrict the output of creative potential // Open University of the Netherlands. - 2011, [PDF HTML kopija] http://www.leefritme.nl/index.php?mod=download\&com=getFile\&id=21 2 [žiūrèta 201205 20];

[11]T.C. DiLiello, Houghton J.D. Creative Potential and Practised Creativity: Identifying Untapped Creativity in Organizations // Creativity and Innovation Management / Blackwell Publishing Ltd. - 2008, Vol. 17, Nr. 1, p. 37-46. - Online ISSN 1467-8691;

[12] European commission. Innovation Union Scoreboard 2011. ISBN 97892-79-23174-2 http://ec.europa.eu/enterprise/policies/innovation/files/ius2011 en.pdf [žiūrèta 201209 14]

[13]G. et al. Fischer, Beyond binary choices: Integrating individual and social creativity // The International Journal of Human-Computer Studies / Elsevier Ltd. - 2005, Nr. 63, p. 482-512. - ISSN 1071-5819;

[14]A. Jakubavičius, ir kt. Inovacijos versle: procesai, parama, tinklaveika: Mokymo priemonè. - Vilnius: Lietuvos inovaciju centras, 2008. - $180 \mathrm{p}$ - ISBN 978-9955-843-00-9, [PDF HTML kopija]. http://estud.vgtu.lt/users/files/dest/10502/inovacijos_versle.pdf [žiūrèta 201108 $10]$;

[15]S. Ko, J.E. Butler, Creativity: A key link to entrepreneurial behaviour // Business Horizons / Elsevier Ltd. - 2007, Nr. 50, p. 365-372. - ISSN 0007-6813;

[16]Kūrybiškumo teorija: Kūrybiškumo ir inovaciju mokomoji medžiaga Europos tyrimu institucijoms ir MVI - 2007, [PDF HTML kopija]. http://www.train4creativity.eu/dat/64F39 F38/file.pdf?634491656544282000 [žiūrèta 201107 25];
[17]R. Levickaitè, Kürybingumo fenomenas kaip kompleksinio reiškinio evoliucija = Phenomenon of Creativity as Evolution of Integrated Phenomenon // Logos: religijos, filosofijos ir meno žurnalas. - Vilnius, 2010, Nr. 63, Balandis-Birželis, p. 201-212. - ISSN 0868-7692;

[18]Lietuvos Respublikos statistikos departamentas. Lietuvos paslaugu sektoriaus ¿̇moniu rodikliai, 2012. http://www.stat.gov.lt/lt/pages/view/?id=2430 [žiūrèta 201207 25];

[19]Lietuvos statistikos departamentas. Lietuvos mokslo ir technologijas apibūdinantys rodikliai. 2012 http://db1.stat.gov.1t/statbank/default.asp?w=1600 [žiūrèta 201107 25];

[20]G.B. Magee, Rethinking invention: cognition and the economics of technological creativity // Journal of Economic Behavior \& Organization / Elsevier Ltd. - 2005, Vol. 57, p. 29-48. - ISSN 0167-2681;

[21]C. Marin, The Role of Creativity in Romanian Companies // Acta Universitatis Danubius. Economica. - Galati: Danubius University of Galati, Romania, 2007, Nr. 1, p. 29-39. - Online ISSN 2067 - 340X;

[22]Y. Martens, Creative workplace: instrumental and symbolic support for creativity // Facilities: Journal of the Emerald Built Environment Subject Collection / Emerald Group Publishing Ltd. - 2011, Vol. 29, Nr. 1/2, p. 63-79. - ISSN 0263-2772;

[23] N.M. Mostert, Diversity of the mind as the Key to Successful Creativity at Unilever // Creativity and Innovation Management / Blackwell Publishing. - 2007, Vol. 16, Nr. 1, p. 93-100. - Online ISSN 1467-8691;

[24]C. Pak-keung, Can creativity be learned: a knowledge management approach to creativity support: $\mathrm{PhD}$ thesis. - Hong Kong: University of Hong Kong, 2006. - 190 p. - URL: http:// hdl.handle.net/10722/50239;

[25]P. Schepers, P. T. van den Berg, Social factors of work-environment creativity // Journal of Business and Psychology / Worldwide publishing group Springer Science+Business Media - 2007, Vol. 21, Nr. 3, p. 407428. - Online ISSN 1573-353X;

[26]S. A. Seidel, Theory of Managing Creativity-intensive Processes: $\mathrm{PhD}$ thesis. - Muenster, Germany: University of Muenster, 2009. - 251 p. URL: http://miami.uni-muenster.de/servlets/ DerivateServlet/Derivate5053/diss_seidel.pdf;

[27]M. Sundgren, A. Styhre, Creativity and the fallacy of misplaced concreteness in new drug development: A Whiteheadian perspective // European Journal of Innovation Management: Journal of the Emerald Enterprise and Innovation Subject Collection / Emerald Group Publishing Ltd. - 2007, Vol. 10, Nr. 2, p. 215-235. - ISSN 1460-1060;

[28]R.W. Woodman, Creative Action in Organizations: Ivory Tower Visions and Real World Voices / Edited by Cameron M. Ford, Dennis A. Gioia. London: Sage Publications Inc., 1995. - 424 p. - ISBN 0-8039-5349-6, ISBN 0-8039-5350-X (pbk.).

[29]R.W. et al. Woodman, Toward a Theory of Organizational Creativity // The Academy of Management Review / Academy of Management. 1993, Vol. 18, Nr. 2, p. 293-321. - ISSN (printed) 0363-7425, ISSN (electronic) 1930-3807;

Prof. Dr. Irena Mačerinskiene is the Head of the Department of Banking and Investments at the Faculty of Economics and Finance Management of Mykolas Romeris University, Lithuania. Scientific interest covers intellectual capital, social capital, banks, finance and small and medium-sized business. Address: Ateities pl. 20, Vilnius, Lithuania. E-mail: irena.macerinskiene@mruni.eu.

Aleksandra Bulygina holds a Master of Science degree, works at the Department of Banking and Investments at the Faculty of Economics and Finance Management of Mykolas Romeris University, Lithuania. Scientific interest covers creativity, innovativeness, business. E-mail: aleksandra.bulygina@yahoo.com

\section{Irēna Mačerinskienè, Aleksandra Buligina. Kreativitātes un inovāciju novērtēšanas koncepcija uzṇēmumos}

Rakstā ir veikta Lietuvas pakalpojumu uzṇēmumu kreativitātes un inovāciju līmeṇa analīze. Inovāciju attīstības rādītāji Lietuvā ir zemāki par vidējiem ES rādītājiem, un inovāciju darbības attīstība uzn̄ēmumu konkurētspējas pasaulē kontekstā, ir nepietiekama. Pēc mūsdienu zinātnieku viedokla, kreativitāte ir viens no svarīgākajiem inovāciju skaitu ietekmējošajiem faktoriem, tāpēc rakstā pievērsta uzman̄ība galvenajiem faktoriem, kas mijiedarbojas ar kreativitātes attīstību organizācijās. Raksta pirmajā daḷā veikta kreativitātes līmeña un inovāciju attīstības teorētisko metožu analīze, lai radītu priekšstatu par empīriskā pētījuma principiem. Pētījumā izmantotas tādas metodes kā konceptualizācija un operacionalizācija, deduktīvās un induktīvās loǵiskās domāšanas metode, analoǵiju metode, interpretācija un modelē̌sana. Pakalpojumu uzñēmumu kreativitātes novērtēšanai statistiskie dati izrādījās nepietiekami, tāpēc tika izmantota ar̄̄ pakalpojumu uznēmumu aptauja, veicot anketēšanu. Pētījums parādīja, ka kreativitāte pakalpojumu sektorā nav pietiekami novērtēta. Kreatīva darbība tiek minimāli atbalstīta, turklāt ir vērojama informācijas un zināšanu nepietiekamība par nosacījumiem, kas ir svarīgi, lai attīstītu kreativitāti un inovāciju darbību. Respondenti savu kreativitātes līmeni vērtē kritiski, tāpēc ka ir ierobežotas kreatīvu ideju attīstības iespējas. Pētījumi kreatīvu ideju veicināšanā pakalpojumu jomā parādīja arī motivācijas sistēmu ierobežotību. Lielākajā dạ̦ā gadījumu tas ir skaidrojams ar respondentu nepietiekamu motivāciju, turklāt organizāciju vadība neveicina darbinieku kreativitāti inovatīvu ideju radīšanā, nav pietiekama atbalsta darba kolektīvā un ir nelabvēlīga darba atmosfēra, kas tiek uzskatīta par 
svarīgu elementu kreativitātes līmeṇa uzturēšanā uzṇēmumos. Lietuvas pakalpojumu uzṇēmumos ir vērojama darbinieku savstarpēja neuzticēšanās, kas veido galvenos šķēršlus inovāciju radīšanas procesā. Kreativitātes līmenis ir saistīts ar cilvēkresursu līmeni un organizācijas iekšējo vidi. Radoša organizācijas vide, kā galvenais motivācijas sistēmas faktors, var stimulēt kreativitātes un inovāciju atț̄istības procesu pakalpojumu uzṇēmumos.

Ирена Марценкявичене, Александра Булыгина. Концепция оценки креативности и инноваций в предпринимательских организациях

Данная статья посвящается анализу уровня креативности и развития инноваций в литовских предпринимательских организациях в сфере услуг. Показатели развития инноваций в Литве занимают позиции ниже показателей среднего уровня ЕС, а развитие инновационной деятельности с точки зрения увеличения конкурентоспособности предприятий в мировом пространстве является недостаточным. По мнению ряда современных учёных, креативность является важнейшим фактором в создании наибольшего количества инноваций, поэтому статья сконцентрирована на анализе ряда главных факторов, взаимодействующих с развитием креативности в организациях. Первая часть статьи представляет собой анализ теоретической методики по оценке уровня креативности и развития инноваций, позволяющий создать лучшее представление о принципах эмпирического исследования. В исследовании был использован ряд методов, таких как концептуализация и операционализация, метод дедуктивного и индуктивного логического мышления, применение аналогий, метод интерпретации, а так же метод моделирования. Для установления креативности предприятий сектора услуг, анализ статистических данных оказался недостаточным, поэтому, в качестве дополнения, был проведен анкетный опрос ряда литовских предприятий в секторе услуг. Как показало исследование, креативность в данном секторе недооценивается. Креативная деятельность поощряется в минимальном порядке, кроме того, прослеживается дефицит информации и знаний о предпосылках, являющихся необходимыми в процессе развития креативной и инновационной деятельности. Результат оценки собственного уровня креативности респондентами носит критичный характер, главной причиной в такой ситуации является ограниченность возможностей в развитии креативных идей. Данные исследования о поощрении за развитием креативных идей в секторе услуг также показали ограниченность мотивационной системы. В большинстве случаев, это объясняется недостаточной мотивацией респондентов, кроме того, руководство в организациях не поощряет креативности сотрудников и развития инновационных идей, организации сталкиваются со слабой поддержкой в рабочем коллективе и неблагоприятной рабочей атмосферой, которая считается важным элементом, поддерживающим креативный уровень предприятий. В литовских организациях в секторе услуг выражается нехватка доверия работников друг к другу внутри предприятий, что создает главное препятствие на пути создания инноваций. Уровень креативности является связанным с уровнем человеческих ресурсов и внутренней средой организации. Творческая внутренняя среда организации как главный фактор мотивационной системы может создать толчок в процессе развития креативности и инноваций в предприятиях сектора услуг. 